Article

\title{
Computational Estimation of the Acidities of Pyrimidines and Related Compounds ${ }^{\dagger}$
}

\author{
Rachael A. Holt and Paul G. Seybold *
}

Department of Chemistry, Wright State University, Dayton, OH 45435, USA; rachaelannholt@gmail.com

* Correspondence: paul.seybold@wright.edu

t Dedicated to Prof. Frank Weinhold on the occasion of his 80th birthday.

\begin{abstract}
Pyrimidines are key components in the genetic code of living organisms and the pyrimidine scaffold is also found in many bioactive and medicinal compounds. The acidities of these compounds, as represented by their $\mathrm{pK}_{\mathrm{a}} \mathrm{s}$, are of special interest since they determine the species that will prevail under different $\mathrm{pH}$ conditions. Here, a quantum chemical quantitative structure-activity relationship (QSAR) approach was employed to estimate these acidities. Density-functional theory calculations at the B3LYP $/ 6-31+G(d, p)$ level and the SM8 aqueous solvent model were employed, and the energy difference $\Delta \mathrm{E}_{\mathrm{H} 2 \mathrm{O}}$ between the parent compound and its dissociation product was used as a variation parameter. Excellent estimates for both the cation $\rightarrow$ neutral $\left(\mathrm{pK}_{\mathrm{a} 1}, \mathrm{R}^{2}=0.965\right)$ and neutral $\rightarrow$ anion $\left(\mathrm{pK}_{\mathrm{a} 2}, \mathrm{R}^{2}=0.962\right)$ dissociations were obtained. A commercial package from Advanced Chemical Design also yielded excellent results for these acidities.
\end{abstract}

Keywords: pyrimidines; acidities; $\mathrm{pK}_{\mathrm{a}}$; density-functional theory; QSAR

check for updates

Citation: Holt, R.A.; Seybold, P.G Computational Estimation of the Acidities of Pyrimidines and Related Compounds. Molecules 2022, 27, 385. https://doi.org/10.3390/ molecules27020385

Academic Editor: Cosimo Damiano Altomare

Received: 25 November 2021

Accepted: 1 January 2022

Published: 7 January 2022

Publisher's Note: MDPI stays neutral with regard to jurisdictional claims in published maps and institutional affiliations.

Copyright: (C) 2022 by the authors. Licensee MDPI, Basel, Switzerland. This article is an open access article distributed under the terms and conditions of the Creative Commons Attribution (CC BY) license (https:// creativecommons.org/licenses/by/ $4.0 /)$.

\section{Introduction}

Pyrimidines play a central role in the terrestrial genetic code and the pyrimidine framework is also found in many bioactive compounds and medicines. As measurements of molecular properties are frequently difficult or expensive, it is of interest to develop theoretical means for estimating these properties. Among the most important and interesting properties of the pyrimidines are their acidities, as represented by their $\mathrm{pK}_{\mathrm{a}}$ values, which determine the forms of the compounds that will prevail in solution under different $\mathrm{pH}$ conditions. As a result, there has been a long-standing interest in estimating the $\mathrm{pK}_{\mathrm{a}} \mathrm{s}$ of chemical compounds using theoretical approaches [1,2]. This interest continues, as demonstrated by the broad range of methods employed in recent $\mathrm{pK}_{\mathrm{a}}$ studies [3-10]. In an earlier study by our group [11], we presented computational estimates of the $\mathrm{pK}_{\mathrm{a}} \mathrm{s}$ of the biologically related purines and indoles. In the present work we develop estimates for the acidities of pyrimidines and related compounds.

Three main approaches have been used in studies estimating compound acidities [1,12]. In the first approach, first-principles or absolute $\mathrm{pK}_{\mathrm{a}} \mathrm{s}$ are determined in a straight-forward manner using direct calculations, often relying on a thermodynamic cycle to separate different hypothetical stages $[13,14]$. The advantage of this approach is that it follows standard procedures and does not depend on prior knowledge of experimental results. Its disadvantage is that it normally requires a high level of computational effort to achieve reasonable accuracy. A second approach employs the development of an appropriate Quantitative Structure-Activity Relationship (QSAR) for the acidities of a set of compounds [2,15]. This approach requires first the collection of measured experimental $\mathrm{pK}_{\mathrm{a}}$ values for the set and then the identification of some suitable molecular parameter that is closely related to the acidity. An advantage of this approach is that it can generally achieve high accuracy while employing more modest computational efforts, and it accordingly allows the estimation of the $\mathrm{pK}_{\mathrm{a}} \mathrm{s}$ of related, unreported compounds using the same modest computational effort. 
Furthermore, digressions from the derived regression algorithms (i.e., outliers) can alert practitioners to compounds that may be exhibiting behaviors different from the others in the sample [16-18]. In a third approach, a number of commercial programs use algorithms derived from large acidity databases and employ empirical parameters such as Hammett constants to estimate $\mathrm{pK}_{\mathrm{a}} \mathrm{s}[19,20]$. The latter two approaches were employed in the present study.

As noted, the QSAR approach relies on the discovery of some parameter or property of the compounds examined that correlates with the activity of interest, in the present case the $\mathrm{pK}_{\mathrm{a}}$. In many cases, partial atomic charges have been employed as variation parameters for acidities and other properties. However, because the notion of an "atomic charge" in a molecule is not a proper quantum chemical observable, a variety of different approximate schemes have been developed to represent these atomic charges. Of these proposed schemes, our own group [21-24] and others [5,25-27] have found the natural population analysis (NPA) orbitals and charges developed by Weinhold et al. [28-30] to be especially useful in this role. More recently, we have also used another parameter, the energy difference $\Delta \mathrm{E}_{\mathrm{H} 2 \mathrm{O}}$ between the parent compound and its main dissociation product for this purpose. It is this parameter that was employed in the present study.

A particular difficulty arises in a study of the pyrimidines because these compounds do not typically appear as a single species in gas phase or solution, but rather are present as a collection of related tautomers, a situation that also prevailed in our earlier study of purines [11]. Accordingly, some accommodation must be made for this condition, as will be described in the following section.

\section{Methods}

Our aim in a recent series of reports has been to design and evaluate a QSAR protocol suitable for producing accurate $\mathrm{pK}_{\mathrm{a}}$ estimates for selected classes of compounds while employing relatively modest and commonly available computational tools.

The initial step in a $\mathrm{pK}_{\mathrm{a}}$ QSAR study involves the collection of reported experimental $\mathrm{pK}_{\mathrm{a}}$ values from the literature for the class of compounds of interest. In the present case, values for both the cation-to-neutral dissociation, $\mathrm{AH}_{2}{ }^{+} \rightarrow \mathrm{AH}+\mathrm{H}^{+}$, which we will designate $\mathrm{pK}_{\mathrm{a} 1}$, and the neutral-to-anion dissociation, $\mathrm{AH} \rightarrow \mathrm{A}^{-}+\mathrm{H}^{+}$, which we will call $\mathrm{pK}_{\mathrm{a} 2}$, were available for a number of pyrimidines and related compounds. These values are tabulated in Table 1. Given in Table 1 also are computed $\mathrm{pK}_{\mathrm{a}}$ values obtained from the Advanced Chemical Development (ACD) [31] commercial software package.

Table 1. Reported experimental $\mathrm{pK}_{\mathrm{a} 1}$ and $\mathrm{pK}_{\mathrm{a} 2}$ values and $\mathrm{ACD}$ computed values for the pyrimidines and related heterocycles studied.

\begin{tabular}{|c|c|c|c|c|c|c|}
\hline No. & Compound & Formula & $\mathrm{pK} \mathrm{K}_{\mathrm{a} 1}$ & $\mathrm{ACD} \mathrm{pK}_{\mathrm{a} 1}$ & $\mathrm{pK}_{\mathrm{a} 2}$ & $\begin{array}{l}\mathrm{ACD} \\
\mathrm{pK}_{\mathrm{a} 2}\end{array}$ \\
\hline 1 & azauracil & $\mathrm{C}_{3} \mathrm{H}_{3} \mathrm{~N}_{3} \mathrm{O}_{2}$ & - & $-4.4 \pm 0.2$ & - & $7.8 \pm 0.2$ \\
\hline 2 & aziridine & $\mathrm{C}_{2} \mathrm{H}_{5} \mathrm{~N}$ & 7.98 [32], 8.05 [33] & $8.1 \pm 0.2$ & - & - \\
\hline 3 & creatinine & $\mathrm{C}_{4} \mathrm{H}_{7} \mathrm{~N}_{3} \mathrm{O}$ & $4.8[34]$ & $4.8 \pm 0.1$ & - & - \\
\hline 4 & cytosine & $\mathrm{C}_{4} \mathrm{H}_{5} \mathrm{~N}_{3} \mathrm{O}$ & $\begin{array}{c}4.32[30], 4.58[35], \\
4.6[31]\end{array}$ & $4.4 \pm 0.1$ & 13 [33], 12.15 [36] & $12.3 \pm 0.1$ \\
\hline 5 & flucytosine & $\mathrm{C}_{4} \mathrm{H}_{3} \mathrm{FN}_{2} \mathrm{O}_{2}$ & $3.26[34]$ & $2.6 \pm 0.1$ & - & $10.5 \pm 0.1$ \\
\hline 6 & imidazole & $\mathrm{C}_{3} \mathrm{H}_{4} \mathrm{~N}_{2}$ & $7.15[33], 6.99[34,35]$ & $7.2 \pm 0.6$ & $14.44[33]$ & $13.9 \pm 0.1$ \\
\hline 7 & 1-methylimidazole & $\mathrm{C}_{4} \mathrm{H}_{6} \mathrm{~N}_{2}$ & $6.95[34]$ & $7.0 \pm 0.1$ & $\mathrm{~N} / \mathrm{A}$ & - \\
\hline 8 & 4-methylimidazole & $\mathrm{C}_{4} \mathrm{H}_{6} \mathrm{~N}_{2}$ & $7.55[35]$ & $7.7 \pm 0.6$ & - & $14.3 \pm 0.1$ \\
\hline 9 & isocytosine & $\mathrm{C}_{4} \mathrm{H}_{5} \mathrm{~N}_{3} \mathrm{O}$ & $4.01[34]$ & $3.4 \pm 0.5$ & $9.42[36]$ & $9.6 \pm 0.4$ \\
\hline 10 & isoxazole & $\mathrm{C}_{3} \mathrm{H}_{6} \mathrm{NO}$ & $-2.0[34]$ & $-2.0 \pm 0.5$ & $\mathrm{~N} / \mathrm{A}$ & \\
\hline
\end{tabular}


Table 1. Cont.

\begin{tabular}{|c|c|c|c|c|c|c|}
\hline No. & Compound & Formula & $\mathrm{pK}_{\mathrm{a} 1}$ & $\mathrm{ACD} \mathrm{pK}_{\mathrm{a} 1}$ & $\mathrm{pK}_{\mathrm{a} 2}$ & $\begin{array}{l}\mathrm{ACD} \\
\mathrm{pK}_{\mathrm{a} 2}\end{array}$ \\
\hline 11 & maleimide & $\mathrm{C}_{4} \mathrm{H}_{3} \mathrm{NO}_{2}$ & - & $-5.7 \pm 0.2$ & $9.46[37]$ & $8.5 \pm 0.2$ \\
\hline 12 & morpholine & $\mathrm{C}_{4} \mathrm{H}_{9} \mathrm{NO}$ & $8.492[35]$ & $9.0 \pm 0.2$ & $\mathrm{~N} / \mathrm{A}$ & - \\
\hline 13 & piperidine & $\mathrm{C}_{5} \mathrm{H}_{11} \mathrm{~N}$ & $11.12[35]$ & $10.4 \pm 0.1$ & - & - \\
\hline 14 & piperazine & $\mathrm{C}_{4} \mathrm{H}_{10} \mathrm{~N}_{2}$ & 9.78 [35], 9.73 [34] & $9.6 \pm 0.1$ & - & - \\
\hline 15 & 1-methylpiperazine & $\mathrm{C}_{5} \mathrm{H}_{12} \mathrm{~N}_{2}$ & $10.19[35]$ & $9.3 \pm 0.1$ & - & - \\
\hline 16 & oxazole & $\mathrm{C}_{3} \mathrm{H}_{6} \mathrm{NO}$ & $0.8[34]$ & $1.0 \pm 0.1$ & $\mathrm{~N} / \mathrm{A}$ & - \\
\hline 17 & pyrazine & $\mathrm{C}_{4} \mathrm{H}_{4} \mathrm{~N}_{2}$ & $0.65[34]$ & $1.2 \pm 0.1$ & $\mathrm{~N} / \mathrm{A}$ & - \\
\hline 18 & pyrazole & $\mathrm{C}_{3} \mathrm{H}_{4} \mathrm{~N}_{2}$ & $2.61[35]$ & $2.8 \pm 0.1$ & $14.21[33]$ & $14.0 \pm 0.5$ \\
\hline 19 & pyridazine & $\mathrm{C}_{4} \mathrm{H}_{43} \mathrm{~N}_{2}$ & $2.3[32]$ & $3.1 \pm 0.1$ & $\mathrm{~N} / \mathrm{A}$ & - \\
\hline 20 & pyridine & $\mathrm{C}_{5} \mathrm{H}_{5} \mathrm{~N}$ & $5.23[34]$ & $5.2 \pm 0.1$ & $\mathrm{~N} / \mathrm{A}$ & - \\
\hline 21 & pyrimidine & $\mathrm{C}_{4} \mathrm{H}_{4} \mathrm{~N}_{2}$ & $1.3[32]$ & $1.8 \pm 0.1$ & $\mathrm{~N} / \mathrm{A}$ & - \\
\hline 22 & pyrrole & $\mathrm{C}_{4} \mathrm{H}_{5} \mathrm{~N}$ & $-3.8[34]$ & $-0.3 \pm 0.5$ & $17.0[33]$ & $17.0 \pm 0.5$ \\
\hline 23 & pyrrolidine & $\mathrm{C}_{4} \mathrm{H}_{9} \mathrm{~N}$ & $\begin{array}{c}12.10[33], 11.31 \\
{[34,35]}\end{array}$ & $10.5 \pm 0.1$ & - & - \\
\hline 24 & succinimide & $\mathrm{C}_{4} \mathrm{H}_{5} \mathrm{NO}_{2}$ & - & $-4.4 \pm 0.2$ & $9.62[34,35], 9.68[36]$ & $9.6 \pm 0.1$ \\
\hline 25 & thymine & $\mathrm{C}_{5} \mathrm{H}_{6} \mathrm{~N}_{2} \mathrm{O}_{2}$ & - & $-4.1 \pm 0.4$ & $\begin{array}{c}9.9[33], 9.79[35] \\
9.44[34]\end{array}$ & $9.2 \pm 0.1$ \\
\hline 26 & uracil & $\mathrm{C}_{4} \mathrm{H}_{4} \mathrm{~N}_{2} \mathrm{O}_{2}$ & - & $-4.2 \pm 0.1$ & $9.43[38], 9.45[34,36]$ & $8.9 \pm 0.1$ \\
\hline 27 & 5-bromouracil & $\mathrm{C}_{4} \mathrm{H}_{3} \mathrm{BrN}_{2} \mathrm{O}_{2}$ & - & - & $7.91[38]$ & $6.8 \pm 0.1$ \\
\hline 28 & 5-chlorouracil & $\mathrm{C}_{4} \mathrm{H}_{3} \mathrm{CIN}_{2} \mathrm{O}_{2}$ & - & - & $7.92[38]$ & $6.8 \pm 0.1$ \\
\hline 29 & fluorouracil & $\mathrm{C}_{4} \mathrm{H}_{4} \mathrm{FN}_{3} \mathrm{O}$ & - & - & $\begin{array}{c}8.04[30], 8.00[39], \\
7.93[38]\end{array}$ & $6.7 \pm 0.1$ \\
\hline 30 & 5-formyluracil & $\mathrm{C}_{5} \mathrm{H}_{4} \mathrm{~N}_{2} \mathrm{O}_{3}$ & - & - & $6.84[38]$ & $7.3 \pm 0.1$ \\
\hline 31 & 5-nitrouracil & $\mathrm{C}_{4} \mathrm{H}_{3} \mathrm{~N}_{3} \mathrm{O}_{4}$ & - & - & 5.3 [38] & $5.2 \pm 0.1$ \\
\hline
\end{tabular}

Calculations were carried out using the Spartan'10 software package (Wavefunction, Inc., Irvine, $\mathrm{CA}$ ). In earlier $\mathrm{pK}_{\mathrm{a}}$ studies, we found that density-functional computations at the B3LYP/6-31+G(d,p) level provided accurate accounts of molecular properties while still requiring only modest computational demands. After testing this assumption (vide infra) against available gas-phase experimental results for pyrimidines in the NIST database [40], this level of theory was adopted in the present work. For the studies in aqueous solution, the SM8 aqueous solvent model of Marenich et al. [41,42] was used. This same solvent model was also employed in our earlier study of purines and indoles [11] and other studies $[16,17,43]$, where it was shown to perform well in helping to reproduce the experimental data.

As noted above, many of the compounds examined here exist in several tautomeric forms in solution. (For example, uracil has three cationic tautomers, six neutral tautomers, and two anionic tautomers.) Accordingly, the relative stabilities of the tautomeric formscationic, neutral, and anionic - of each compound were evaluated within the SM8 aqueous solvent model, and the most stable tautomer for each condition was taken as representative of that compound for computational purposes [44]. Fortunately, there frequently exists a substantial energy gap $(>25 \mathrm{~kJ} / \mathrm{mol})$ between the most stable tautomer and the remaining tautomers of that species; however, ultimately the validity of this approximation must await justification from the results of the subsequent analysis. In earlier studies, we found that for neutral $\rightarrow$ anion dissociations $\left(\mathrm{pK}_{\mathrm{a} 2}\right)$ the value $\Delta \mathrm{E}_{\mathrm{H} 2 \mathrm{O}}=\mathrm{E}_{\mathrm{H} 2 \mathrm{O}}\left(\mathrm{A}^{-}\right)-$ 
$\mathrm{E}_{\mathrm{H} 2 \mathrm{O}}(\mathrm{AH})$ for the energy difference between the parent compound $\mathrm{AH}$ and its dissociation product $\mathrm{A}^{-}$in aqueous solution provides an excellent regression parameter for QSAR $\mathrm{pK}_{\mathrm{a}}$ studies, and after testing several other parameters this descriptor was used in the present studies. For the cation $\rightarrow$ neutral dissociation $\left(\mathrm{pK}_{\mathrm{a} 1}\right)$, the analogous expression $\Delta \mathrm{E}_{\mathrm{H} 2 \mathrm{O}}=\mathrm{E}_{\mathrm{H} 2 \mathrm{O}}(\mathrm{AH})-\mathrm{E}_{\mathrm{H} 2 \mathrm{O}}\left(\mathrm{AH}_{2}{ }^{+}\right)$was used.

We also provide a note of caution regarding directly comparing numerical results found here using Spartan'10 with those obtained using the popular Gaussian computational package (Gaussian, Inc., Wallingford, CT 06492, USA), since these programs use different basis sets for some atoms $[18,45]$.

\section{Results and Discussion}

We first wished to assure that the B3LYP/6-31+G(d,p) level of computation was sufficient to provide accurate results for the dissociations in question. For this, we turned to gasphase reaction results reported in the NIST chemical database [24]. This database contains gas-phase thermodynamic data for the Gibbs energy change $\Delta_{\mathrm{r}} \mathrm{G}^{\circ}$ for the anion $+\mathrm{H}^{+} \rightarrow$ neutral reaction, for six of the compounds studied here. These experimental data are compared with our computed $\Delta_{\mathrm{r}} \mathrm{G}^{\circ}$ values in Table 2 (note that $\mathrm{G}^{\circ}\left(\mathrm{H}^{+}\right)$ is $-26.3 \mathrm{~kJ} / \mathrm{mol}$ at $298.15 \mathrm{~K} \mathrm{[1]}$ ). As can be seen, there is very close agreement between the experimental and calculated $\Delta_{\mathrm{r}} \mathrm{G}^{\circ}$ values. With the exception of succinimide, all of the calculated values fall within the estimated experimental errors given in the NIST database. This, and the coefficient of determination of $\mathrm{R}^{2}=0.998$ between the computed and experimental values, suggest that the level of computation described should provide a good account of the reactions to be considered.

Table 2. Experimental and calculated gas-phase $\Delta_{\mathrm{r}} \mathrm{G}^{\circ}$ values $(\mathrm{kJ} / \mathrm{mol})$ for the reaction $\mathrm{A}^{-}+\mathrm{H}^{+} \rightarrow \mathrm{AH}$.

\begin{tabular}{cccc}
\hline Compound & Exp. $\Delta_{\mathbf{r}} \mathbf{G}^{\circ}$ & Calc. $\Delta_{\mathbf{r}} \mathbf{G}^{\circ} \mathbf{b}$ & Calc. $\Delta \mathbf{E}^{\mathbf{b}}$ \\
\hline pyridine & 1601 & 1605 & 1648 \\
\hline pyrazine & 1605 & 1605 & 1643 \\
\hline pyrimidine & 1577 & 1579 & 1614 \\
\hline pyridazine & 1565 & 1562 & 1601 \\
\hline imidazole & 1433 & 1432 & 1466 \\
\hline succinimide & 1414 & 1401 & 1436
\end{tabular}

a From the NIST database, Ref. [40]; ${ }^{\mathrm{b}}$ B3LYP/6-31+G(d,p).

As noted above, in previous studies we have found that the energy difference $\Delta \mathrm{E}_{\mathrm{H} 2 \mathrm{O}}$ between the parent compound and its dissociation product provides an excellent regression variable for $\mathrm{pK}_{\mathrm{a}} \mathrm{QSAR}$ estimations. We first examined employment of the gas-phase $\Delta \mathrm{E}$ values for this purpose. As expected, the use of $\Delta \mathrm{E}_{\text {gas }}$ values yielded good, but not exceptional, correlations for both the $\mathrm{pK}_{\mathrm{a} 1}$ (cation $\rightarrow$ neutral, $\mathrm{R}^{2}=0.707$ ) and $\mathrm{pK}_{\mathrm{a} 2}$ (neutral $\rightarrow$ anion, $\mathrm{R}^{2}=0.874$ ) dissociations.

We next optimized the compounds within the SM8 aqueous solvent model. Using the solvent-optimized structures and the calculated $\Delta \mathrm{E}_{\mathrm{H} 2 \mathrm{O}}$ values for the appropriate reactions, we obtained the following QSAR models:

$$
\begin{aligned}
\mathrm{pK}_{\mathrm{a} 1}(\text { calc. }) & =-0.131( \pm 0.008) \cdot \Delta \mathrm{E}_{\mathrm{H} 2 \mathrm{O}}-151.54( \pm 10) \\
\mathrm{n} & =17, \mathrm{R}^{2}=0.965, \mathrm{~s}=1.25, \mathrm{~F}=145 \\
\mathrm{pK}_{\mathrm{a} 2}(\text { calc. }) & =-0.141( \pm 0.008) \cdot \Delta \mathrm{E}_{\mathrm{H} 2 \mathrm{O}}-159.42( \pm 10) \\
\mathrm{n} & =12, \mathrm{R}^{2}=0.962, \mathrm{~s}=0.612, \mathrm{~F}=304
\end{aligned}
$$

In these equations, $\mathrm{n}=$ the number of compounds in the sample, $\mathrm{R}^{2}$ is the coefficient of determination (the fraction of the variance in the data accounted for by the model), $\mathrm{s}$ is the standard error of the estimate, and F is the Fisher statistic. It is evident that optimization of 
the structures within the solvent model significantly increases the accuracy of the model, as was also shown in earlier work [1,7-9].

The results for $\mathrm{pK}_{\mathrm{a} 1}$ and $\mathrm{pK}_{\mathrm{a} 2}$ are plotted in Figures 1 and 2, and the calculated values are compared with the experimental values in Tables 3 and 4 . We note that several of the $\mathrm{pK}_{\mathrm{a}} \mathrm{s}$ for the cation $\rightarrow$ neutral dissociation $\left(\mathrm{pK}_{\mathrm{a} 1}\right)$ fall into the difficult-to-measure negative value range and carry large uncertainties. Accordingly, these values are also not well characterized for use in this range in forming the regression Equation (1), and we prefer to recognize this uncertainty by simply indicating modestly negative $(<0)$ or significantly negative $(<<0)$ for the $\mathrm{pK}_{\mathrm{a}} \mathrm{s}$ of these compounds.

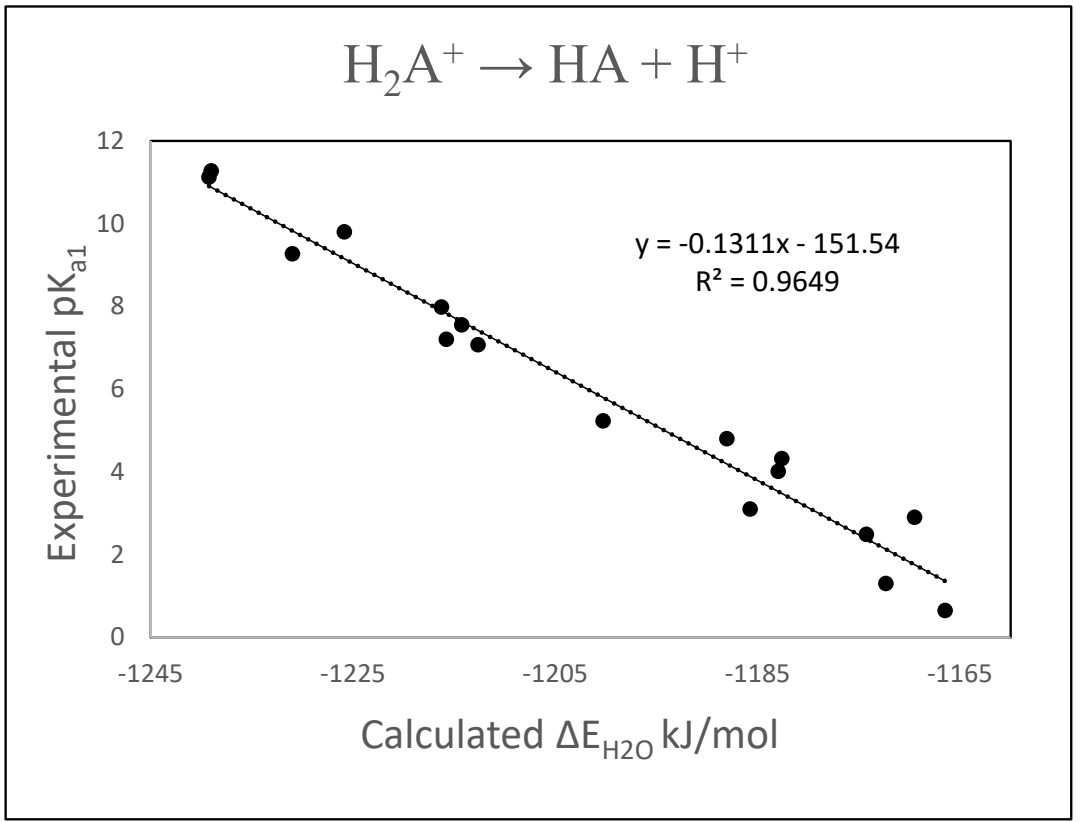

Figure 1. Plot of experimental $\mathrm{pK}_{\mathrm{a} 1} \mathrm{~s}$ vs. calculated $\Delta \mathrm{E}_{\mathrm{H} 2 \mathrm{O}} \mathrm{s}$.

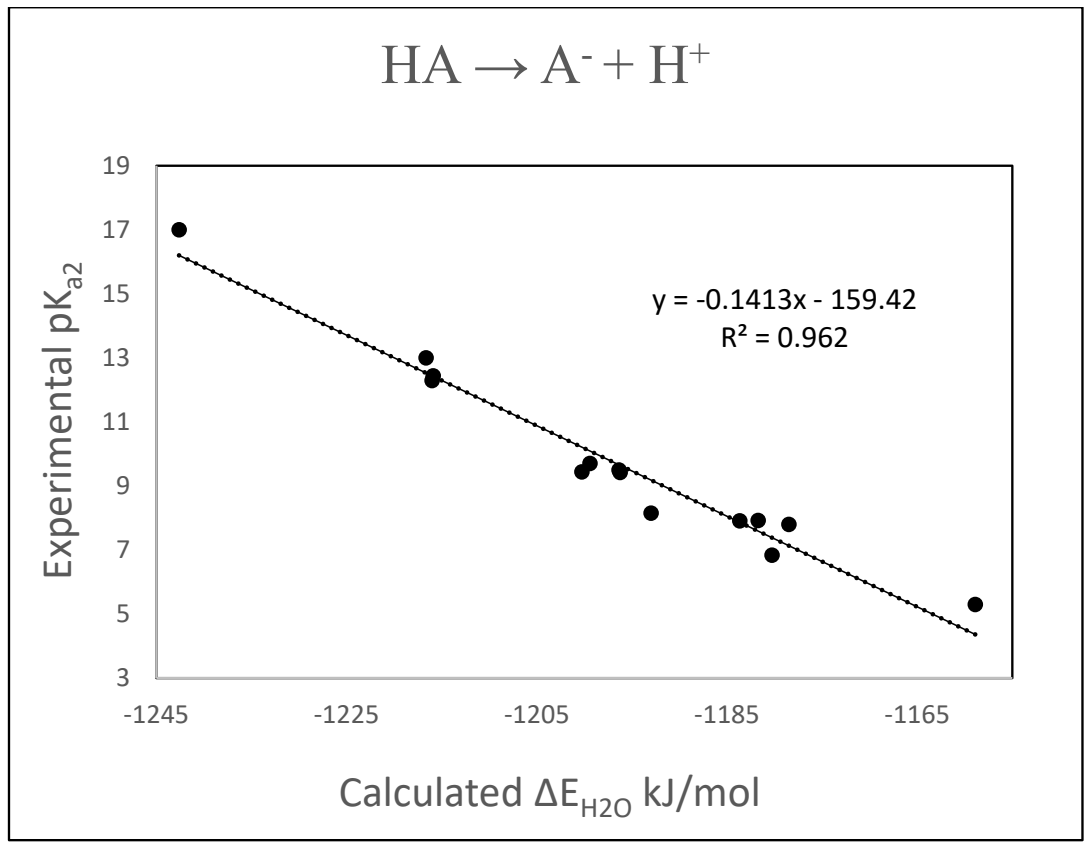

Figure 2. Plot of experimental $\mathrm{pK}_{\mathrm{a} 2} \mathrm{~S}$ vs. calculated $\Delta \mathrm{E}_{\mathrm{H} 2 \mathrm{O}} \mathrm{s}$. 
Table 3. Literature $\mathrm{pK}_{\mathrm{a} 1} \mathrm{~s}$ and estimated $\mathrm{pK}_{\mathrm{a} 1} \mathrm{~s}$.

\begin{tabular}{ccccc}
\hline Compound & $\mathbf{\Delta E} \mathbf{~ k J / m o l}$ & $\mathbf{E x p} \cdot \mathbf{p} \mathbf{K}_{\mathbf{a} \mathbf{1}}$ & Calc. $\mathbf{p} \mathbf{K}_{\mathbf{a} \mathbf{1}} \mathbf{a}$ & Residual \\
\hline azauracil & -1084 & - & $<<0$ & - \\
aziridine & -1216 & 8.01 & 7.76 & 0.25 \\
creatinine & -1188 & 4.8 & 4.09 & 0.71 \\
cytosine & -1183 & 4.5 & 3.43 & 1.07 \\
flucytosine & -1169 & 3.26 & 1.60 & 1.66 \\
imidazole & -1213 & 7.07 & 7.36 & -0.29 \\
1-methylimidazole & -1216 & 7.95 & 7.76 & 0.19 \\
4-methylimidazole & -1215 & 7.55 & 7.63 & -0.08 \\
isocytosine & -1183 & 4.01 & 3.43 & 0.58 \\
isoxazole & -1115 & -2 & $<0$ & - \\
maleimide & -1035 & - & $<<0$ & - \\
oxazole & -872 & 0.8 & $<<0$ & - \\
piperidine & -1239 & 11.12 & 10.77 & 0.35 \\
piperazine & -1226 & 9.76 & 9.07 & 0.69 \\
1-methylpiperazine & -1231 & 10.19 & 9.72 & 0.47 \\
pyrazine & -1166 & 0.65 & 1.21 & -0.56 \\
pyrazole & -1174 & 2.61 & 2.25 & 0.36 \\
pyridazine & -1186 & 2.3 & 3.83 & -1.53 \\
pyridine & -1200 & 5.23 & 5.66 & -0.43 \\
pyrimidine & -1172 & 1.3 & 1.99 & -0.69 \\
pyrrolidine & -1239 & 11.71 & 10.77 & 0.94 \\
succinimide & -1007 & - & $<<0$ & - \\
\hline
\end{tabular}

${ }^{\mathrm{a}} \mathrm{pK}_{\mathrm{a} 1} \mathrm{~s}$ were estimated using Equation (1).

Table 4. Literature $\mathrm{pK}_{\mathrm{a} 2} \mathrm{~s}$ and estimated $\mathrm{pK}_{\mathrm{a} 2} \mathrm{~s}$.

\begin{tabular}{ccccc}
\hline Compound & $\mathbf{\Delta E} \mathbf{~ k J / m o l}$ & Exp. $\mathbf{p} \mathbf{K}_{\mathbf{a} 2}$ & ${\text { Calc. } \mathbf{p} \mathbf{K}_{\mathbf{a} 2} \mathbf{a}}^{\mathbf{a}}$ & Residuals \\
\hline azauracil & -1179 & - & 6.82 & - \\
aziridine & -1325 & - & 27.41 & - \\
creatinine & -1217 & - & 12.18 & - \\
cytosine & -1216 & 12.57 & 12.04 & 0.53 \\
isocytosine & -1196 & 9.42 & 9.22 & 0.20 \\
flucytosine & -1254 & - & 17.39 & - \\
imidazole & -1216 & 14.4 & 12.04 & 2.36 \\
4-methylimidazole & -1224 & - & 13.16 & - \\
maleimide & -1196 & 9.5 & 9.22 & 0.28 \\
piperazine & -1313 & - & 25.71 & - \\
1-methylpiperazine & -1395 & - & 37.28 & - \\
piperidine & -1310 & - & 25.29 & 1.16 \\
pyrrole & -1243 & 17 & 15.84 & - \\
pyrrolidine & -1390 & - & 36.57 & 0.07 \\
thymine & -1199 & 9.71 & 9.64 & -0.34 \\
uracil & -1200 & 9.44 & 9.78 & 0.39 \\
5-bromouracil & -1184 & 7.91 & 7.52 & 0.68 \\
5-chlorouracil & -1182 & 7.92 & 7.24 & -0.80 \\
fluorouracil & -1193 & 7.99 & 8.79 & -0.12 \\
5-formyluracil & -1180 & 6.84 & 6.96 & 1.30 \\
5-nitrouracil & -1159 & 5.3 & 4.00 & \\
\hline
\end{tabular}

${ }^{\mathrm{a}} \mathrm{pK}_{\mathrm{a} 2} \mathrm{~S}$ were estimated using Equation (2).

We also tested the ability of a commercial software program, Advanced Chemical Development, Inc.'s ACD/Labs PhysChem Percepta Suite, to estimate these $\mathrm{pK}_{a} \mathrm{~s}$. The results for $\mathrm{pK}_{\mathrm{a} 1}$ showed an excellent correlation:

$$
\begin{gathered}
\mathrm{pk}_{\mathrm{a} 1}(\exp .)=1.07( \pm 0.03) \cdot \mathrm{pk}_{\mathrm{a} 1}(\mathrm{ACD})+0.34( \pm 0.2) \\
\text { where } \mathrm{n}=19, \mathrm{R}^{2}=0.991, \mathrm{~s}=0.334, \text { and } \mathrm{F}=1583
\end{gathered}
$$


The results for $\mathrm{pK}_{\mathrm{a} 2}$ were also very good:

$$
\begin{gathered}
\mathrm{pK}_{\mathrm{a} 2}(\text { exp. })=0.95( \pm 0.05) \cdot \mathrm{pK}_{\mathrm{a} 1}(\mathrm{ACD})+0.92( \pm 0.52) \\
\text { where } \mathrm{n}=13, \mathrm{R}^{2}=0.966, \mathrm{~s}=0.612, \text { and } \mathrm{F}=316 .
\end{gathered}
$$

These results encourage use of this software for studies of the $\mathrm{pK}_{\mathrm{a}} \mathrm{s}$ of these compounds.

\section{Conclusions}

A primary endeavor of scientific studies is to develop models of physical, chemical, and biological systems for the purpose of understanding these systems better. All models are by their very nature approximate. However, as Gauch has noted [46], in some casescounterintuitively - a model can be more accurate than the data from which it is constructed "because it amplifies hidden patterns and discards unwanted noise" inherent in the system being examined. The QSAR equations used here take advantage of this property by "averaging through" the noise, or random errors, in the experimental $\mathrm{pK}_{\mathrm{a}}$ data. It is evident that both the QSAR Equations (1) and (2) above provide relatively simple means, via mathematical models, for estimating the $\mathrm{pK}_{\mathrm{a}} \mathrm{s}$ of the pyrimidines and related compounds. For example, in order to estimate the $\mathrm{pK}_{\mathrm{a}} \mathrm{s}$ of unmeasured compounds in this class or to check the reported $\mathrm{pK}_{\mathrm{a}} \mathrm{s}$ of measured compounds, using the QSAR equations one merely needs to determine $\Delta \mathrm{E}_{\mathrm{H} 2 \mathrm{O}}$ for the compound and then evaluate the $\mathrm{pK}_{\mathrm{a}}$ from the appropriate regression equation. Therefore, the equations provided should allow reasonable estimations for the $\mathrm{pK}_{\mathrm{a}} \mathrm{s}$ of other pyrimidines and compounds similar to the pyrimidines. Use of the commercial ACD/Labs program can provide a further independent and very useful check on the $\mathrm{pK}_{\mathrm{a}}$ estimates.

Author Contributions: Conceptualization, P.G.S.; formal analysis, R.A.H.; investigation, R.A.H.; supervision, P.G.S.; validation, R.A.H.; writing-original draft, P.G.S. All authors have read and agreed to the published version of the manuscript.

Funding: This research received no external funding.

Data Availability Statement: See Ref. [44] for available data.

Conflicts of Interest: The authors declare no conflict of interest.

Sample Availability: Samples of the compounds are not available from the authors.

\section{References}

1. Shields, G.C.; Seybold, P.G. Computational Approaches for the Prediction of $p K_{a}$ Values; CRC Press: Boca Raton, FL, USA, 2014.

2. Ho, J. Predicting $\mathrm{pK}_{\mathrm{a}}$ in Implicit Solvents: Current Status and Future Directions. Aust. J. Chem. 2014, 67, 1441-1460. [CrossRef]

3. Pracht, P.; Grimme, S. Efficient Quantum-Chemical Calculations of Acid Dissociation Constants from Free-Energy Relationships. J. Phys. Chem. A 2021, 125, 5681-5692. [CrossRef]

4. Morency, M.; Néron, S.; Iftimie, R.; Wuest, J.D. Predicting $\mathrm{pK}$ a Values of Quinols and Related Aromatic Compounds with Multiple OH Groups. J. Org. Chem. 2021, 86, 14444-14460. [CrossRef] [PubMed]

5. Haslak, Z.P.; Zareb, S.; Dogan, I.; Aviyente, V.; Monard, G. Using Atomic Charges to Describe the pKa of Carboxylic Acids. J. Chem. Inf. Model. 2021, 61, 2733-2743. [CrossRef]

6. Thapa, B.; Raghavachari, K. Accurate pKa Evaluations for Complex Bio-Organic Molecules in Aqueous Media. J. Chem. Theory Comput. 2019, 15, 6025-6035. [CrossRef]

7. Hunt, P.; Hosseini-Gerami, L.; Chrien, T.; Plante, J.; Ponting, D.J.; Segall, M. Predicting $\mathrm{p} K_{\mathrm{a}}$ Using a Combination of Semi-Empirical Quantum Mechanics and Radial Basis Function Methods. J. Chem. Inf. Model. 2019, 35, 7896-7904. [CrossRef] [PubMed]

8. Dutra, F.R.; de Souza Silva, C.; Custodio, R. On the Accuracy of the Direct Method to Calculate pKa from Electronic Structure Calculations. J. Phys. Chem. A 2021, 125, 65-73. [CrossRef]

9. Pereira, R.W.; Ramabhadran, R.O. pK-Yay: A Black-Box Method Using Density Functional Theory and Implicit Solvation Models to Compute Aqueous $\mathrm{pK}_{\mathrm{a}}$ Values of Weak and Strong Acids. J. Phys. Chem. A 2020, 124, 9061-9074. [CrossRef] [PubMed]

10. Yang, Q.; Liu, Y.; Zhang, L.; Luo, S.; Cheng, J.-P. Holistic Prediction of the pKa in Diverse Solvents Based on a Machine Learning Approach. Angew. Chem. Int. Ed. 2020, 59, 19282-19291. [CrossRef]

11. Geremia, K.L.; Seybold, P.G. Computational Estimation of the Acidities of Purines and Indoles. J. Mol. Model. 2019, 25, 12. [CrossRef] 
12. Seybold, P.G.; Shields, G.C. Computational estimation of $\mathrm{pK}_{\mathrm{a}}$ values. WIREs Comput. Mol. Sci. 2015, 5, 290-297. [CrossRef]

13. Alongi, K.S.; Shields, G.C. Theoretical Calculations of Acid Dissociation Constants: A Review Article. Ann. Rep. Comput. Chem. 2010, 6, 113-138.

14. Liptak, M.D.; Gross, K.C.; Seybold, P.G.; Feldgus, S.; Shields, G.C. Absolute $\mathrm{pK}_{\mathrm{a}}$ determinations for substituted phenols. J. Am. Chem. Soc. 2002, 124, 6421-6427. [CrossRef]

15. Seybold, P.G. Quantum Chemical QSPR Estimation of the Acidities and Basicities of Organic Compounds. Adv. Quantum Chem. 2012, 64, 83-104.

16. Seybold, P.G. Quantum Chemical Estimation of the Acidities of Some Inorganic Oxoacids. Mol. Phys. 2015, 113, 232-236. [CrossRef]

17. Seybold, P.G. Computational Estimation of the Acidities of Some Inorganic Nitrogen Acids. Mol. Phys. 2016, 114, 389-393. [CrossRef]

18. Baldasare, C.A.; Seybold, P.G. Computational Estimation of the Gas-Phase and Aqueous Acidities of Carbon Acids. J. Phys. Chem. A 2020, 125, 2152-2159. [CrossRef] [PubMed]

19. Liao, C.; Nicklaus, M.C. Comparison of nine programs predicting pKa values of pharmaceutical substances. J. Chem. Inf. Model. 2009, 49, 2801-2812. [CrossRef]

20. Dearden, J.C.; Rotureau, P.; Fayet, G. QSPR prediction of physico-chemical properties for REACH. SAR QSAR Environ. Res. 2013, 34, 279-318. [CrossRef]

21. Gross, K.C.; Seybold, P.G. Substituent Effects on the Physical Properties and $\mathrm{pK}_{\mathrm{a}}$ of Aniline. Int. J. Quantum Chem. 2000, 80, 1107-1115. [CrossRef]

22. Gross, K.C.; Seybold, P.G.; Hadad, C.M. Comparison of Different Atomic Charge Schemes for Predicting pKa Variations in Substituted Anilines and Phenols. Int. J. Quantum Chem. 2002, 90, 445-458. [CrossRef]

23. Gross, K.C.; Hadad, C.M.; Seybold, P.G. Charge Competition in Halogenated Hydrocarbons. Int. J. Quantum Chem. 2011, 112, 219-229. [CrossRef]

24. Scheiner, S.; Seybold, P.G. Quantum chemical analysis of the energetics of the anti and gauche conformers of ethanol. Struct. Chem. 2009, 20, 43-48. [CrossRef]

25. Varekova, R.S.; Geidl, S.; Ionescu, C.-M.; Skrehota, O.; Kudera, M.; Sehnal, D.; Bouchal, T.; Abagyan, R.; Huber, H.J.; Koca, J. Predicting $\mathrm{pK}_{\mathrm{a}}$ Values of Substituted Phenols from Atomic Charges: Comparison of Different Quantum Mechanical Methods and Charge Distribution Schemes. J. Chem. Inf. Model. 2011, 51, 1795-1806. [CrossRef]

26. Ugur, I.; Marion, A.; Parant, S.; Jensen, J.H.; Monard, G. Rationalization of the pKa Values of Alcohols and Thiols Using Atomic Charge Descriptors and Its Application to the Prediction of Amino Acid pKa's. J. Chem. Inf. Model. 2014, 54, 2200-2213. [CrossRef]

27. Mull, H.F.; Turney, J.M.; Douberly, G.E.; Schaefer, H.F., III. Kinetic Stability of Pentazole. J. Phys. Chem. A 2021, 125, 9092-9098. [CrossRef]

28. Reed, A.E.; Curtiss, L.A.; Weinhold, F. Natural population analysis. J. Chem. Phys. 1985, 83, 735-746. [CrossRef]

29. Reed, A.E.; Curtiss, L.A.; Weinhold, F. Intermolecular Interactions from a Natural Bond Orbital, Donor-Acceptor Viewpoint. Chem. Rev. 1988, 88, 899-926. [CrossRef]

30. Glendening, E.D.; Landis, C.R.; Weinhold, F. Natural Bond Orbital Methods. WIREs Comput. Mol. Sci. 2012, 2, 1-42. [CrossRef]

31. Advanced Chemistry Development, Inc.: Toronto, ON, Canada. Available online: https://www.acdlabs.com/ (accessed on 24 November 2021).

32. Katritzky, A.R.; Ramsden, C.A.; Joule, J.A.; Zhdankin, V.V. Handbook of Heterocyclic Chemistry, 3nd ed.; Elsevier: New York, NY, USA, 2010

33. Serjeant, E.P.; Dempsey, B. Ionization Constants of Organic Acids in Aqueous Solution; UPAC Chemical Data Series-No. 23; International Union of Pure and Applied Chemistry: Oxford, UK, 1979.

34. CRC Handbook of Chemistry and Physics, 89th ed.; CRC Press: Boca Raton, FL, USA, 2008.

35. Dean, J.A. Lange's Handbook of Chemistry, 13th ed.; McGraw-Hill: New York, NY, USA, 1985.

36. Levene, P.A.; Bass, L.W.; Simms, H.S. The ionization of pyrimidines in relation to the structure of pyrimidine nucleosides. J. Biol. Chem. 1926, 70, 229-241. [CrossRef]

37. Darnall, K.R.; Townsend, L.B.; Robins, R.K. The structure of showdomycin, a novel carbon-linked nucleoside antibiotic related to uridine. Proc. Nat. Acad. Sci. USA 1967, 57, 548-553. [CrossRef]

38. Privat, E.J.; Sowers, L.C. A proposed mechanism for the mutagenicity of 5-formyluracil. Mutat. Res. 1996, 354, 151-156. [CrossRef]

39. Handschmacher, R.E.; Welch, A.D. Microbial studies of 6-azauracil, an antagonist of uracil. Cancer Res. 1956, 16, 965-969.

40. NIST Chemistry WebBook. Available online: http://webbook.nist.gov/chemistry/ (accessed on 13 July 2016).

41. Marenich, A.V.; Olson, R.M.; Kelly, C.P.; Cramer, C.J.; Truhlar, D.G. Self-consistent reaction field model for aqueous and nonaqueous solutions based on accurate polarized partial charges. J. Chem. Theory Comput. 2007, 3, 2011-2033. [CrossRef] [PubMed]

42. Cramer, C.J.; Truhlar, D.G. A Universal Approach to Solvation Modeling. Accts. Chem. Res. 2008, 41, 760-768. [CrossRef] [PubMed]

43. Hunter, N.E.; Seybold, P.G. Theoretical estimation of the aqueous $\mathrm{pK}_{\mathrm{a}} \mathrm{s}$ of thiols. Mol. Phys. 2014, 112, 340-348. [CrossRef]

44. Wessner, R.A. Theoretical Estimation of $\mathrm{pK}_{\mathrm{a}} \mathrm{s}$ of Pyrimidines and Related Heterocycles. Master's Thesis, Wright State University, Dayton, OH, USA, 2016.

45. Scheiner, S.; Seybold, P.G. (Utah State University, Logan, Utah). Unpublished work. 2009.

46. Gauch, H.G., Jr. Prediction, Parsimony and Noise. Am. Sci. 1993, 81, 468-478. 